\title{
Settlement on Lusignan Cyprus after the Latin Conquest: The Accounts of Cypriot and other Chronicles and the Wider Context
}

\author{
Osadnictwo na Cyprze Lusignanów po podboju \\ łacińskim. Analiza kronik cypryjskich i innych \\ w szerszym kontekście
}

\begin{abstract}
In the article "Settlement on Lusignan Cyprus after the Latin Conquest: The Accounts of Cypriot and other Chronicles and the Wider Context" the narratives of various chronicles of the thirteenth to the sixteenth centuries on settlement in Cyprus in the years following the Latin conquest, from the end of the twelfth to the early thirteenth century, will be examined and compared. The details provided by the chronicles, where the information given derived from, the biases present in the various accounts, the extent to which they are accurate, especially in cases where they are corroborated or refuted by documentary evidence, will all be discussed. The chronicles that will be referred to are the thirteenth century continuation of William of Tyre, that provides the fullest account of the settlement of Latin Christians and others on Cyprus after the Latin conquest, the fifteenth century chronicle of Leontios Makhairas, the anonymous chronicle of 'Amadi' that
\end{abstract}


is probably dateable to the early sixteenth century although for the section on thirteenth century Cypriot history it draws on earlier sources and the later sixteenth century chronicle of Florio Bustron. Furthermore, the Chorograffia and the Description of Stephen de Lusignan, two chronicles postdating the conquest of Cyprus by the Ottoman Turks in 1570, will also be referred to on the subject of settlement in thirteenth century Cyprus. By way of comparison, the final part of the paper examined the extent to which the evidence of settlement in other Mediterranean lands derives chiefly from chronicles or from documentary sources. In conclusion, it can be stated that the various accounts of settlement on Cyprus following its cession to King Guy of Jerusalem in 1192 show differences in terms of the value of the fiefs, the geographical regions from which the settlers came and the types of properties which were granted to them. The Latin kingdom of Jerusalem resembles Cyprus in that the source material for early Latin settlement is narrative, not documentary. But this is not the case for the Venetian Crete and the Hospitaller Rhodes, where the source materials recording the arrival of the first Latin settlers are wholly documentary.

Keywords: chronicles, settlement, conquest, Guy de Lusignan, Latins, Jerusalem, Europe, Syria

\begin{abstract}
Abstrakt
Artykuł "Osadnictwo na Cyprze Lusignanów po podboju łacińskim: analiza kronik cypryjskich i innych w szerszym kontekście" stawia sobie za cel przebadanie i porównanie relacji z różnych kronik z XIII do XVI wieku, dotyczących osadnictwa na Cyprze po podboju łacińskim, czyli od końca XII do początku XIII wieku. Omówione zostaną również szczegółowe informacje zawarte w tych kronikach, zarówno pod kątem rozbieżności, które są wynikiem uprzedzeń i stronniczości, jak również pod względem wiarygodności, która zostanie zweryfikowana na podstawie dostępnych źródeł z epoki. Źródła narracyjne, o których mowa, to XIII-wieczna kontynuacja kroniki Wilhelma z Tyru, która dostarcza najpełniejszego opisu osadnictwa łacińskiego i innego na Cyprze po podboju łacińskim; XV-wieczna kronika Leontiosa Makhairasa; anonimowa kronika znana jako „Amadi”, którą można prawdopodobnie datować na początek XVI wieku, chociaż w części dotyczącej XIII-wiecznej historii Cypru czerpie z wcześniejszych źródeł; kronika Florio Bustrona z XVI wieku; dwie kroniki Stefana z Lusignan - "Chorografia” i „Opis Cypru”- obydwie datowane na okres po podboju Cypru przez Turków osmańskich w 1570 roku.

W końcowej części artykułu zbadano, w jakim stopniu informacje o osadnictwie na innych terenach śródziemnomorskich pochodzą z kronik,
\end{abstract}


a w jakim ze źródeł dokumentowych. Podsumowując, można stwierdzić, że różne relacje o osadnictwie na Cyprze po przekazaniu wyspy w 1192 roku Gwidonowi z Lusignan (Guy de Lusignan), królowi Jerozolimy, wykazują różnice pod względem wartości lenn, regionów geograficznych, z których przybyli osadnicy, oraz rodzajów posiadłości, które zostały im przyznane. Łacińskie królestwo Jerozolimy przypomina Cypr pod tym względem, że baza źródłowa dotycząca wczesnego osadnictwa łacińskiego oparta została na materiałach narracyjnych, a nie na dokumentach. Inaczej mają się sprawy w przypadku weneckiej Krety i Rodos pod władaniem Zakonu Szpitalników - tam informacje o przybyciu pierwszych osadników łacińskich zawarte są w całości w źródłach dokumentowych.

Słowa klucze: kroniki, osadnictwo, podbój, Guy de Lusignan, łacinnicy, Jerozolima, Europa, Syria

\section{Introduction}

The evidence presented by the chronicles overall, despite differences in detail, ideological orientation and time, is fairly consistent as far as the geographical origins, confessional allegiance and ethnicity of the people settling in Cyprus after 1192 is concerned. This evidence is also consistent in seeing the settlement on early Lusignan Cyprus as a result of royal encouragement, especially on the part of Guy de Lusignan, the first Latin ruler of Cyprus, and a consequence of the desire of Christians in the eastern Mediterranean basin to come to Cyprus to escape from lands conquered by the Muslims as a result of Saladin's victories over the Latin Christians. Looking at the issue more broadly, one discovers that contemporary documentary evidence for the settlement taking place on Cyprus immediately after the Latin conquest is exiguous. The few extant documents corroborate in general the evidence of the chronicles. In order to place the evidence of settlement from Cyprus, both chronicles and documents, in a wider context, the evidence for the settlement of Latins in the Holy Land after the First Crusade, of Latins in Crete and the Peloponnese after the Fourth Crusade and of Latins on Rhodes after the Hospitaller conquest of the island in 1309 will also be examined and discussed. 


\section{Cypriot and other Chronicles of the $13^{\text {th }}$ to the $16^{\text {th }}$ centuries}

Of the various chronicles mentioning settlement on Cyprus the Lyon manuscript of the text known as La Continuation de Guillaume de Tyr (1184-1197) containing the most detailed account of the events of 11841197 found in the various continuations of Archbishop William of Tyre's history ends its narration in 1248 and was written in the middle of the thirteenth century. Called the Lyon Eracles on account of Archbishop William's reference to the Byzantine Emperor Heraclius at the start of his own history, it also gives the most detailed version of settlement on Cyprus following King Richard I of England's conquest of the island from the Byzantine usurper Isaac Comnenus ${ }^{1}$. It begins by stating that Guy de Lusignan, the dispossessed king of the Latin kingdom of Jerusalem, solicited Saladin's advice on taking possession of Cyprus on how to safeguard his dominion over it. Saladin advised him 'to give it all away' if he wished to secure his rule there, advice that Guy followed assiduously. As the Lyon Eracles states:

Now I shall tell you what King Guy did when he had taken seisin of the island of Cyprus. He sent messengers to Armenia, to Antioch, to Acre and throughout the land saying that to all those who wished to come and dwell in Cyprus he would give generously so that they might live. The knights, sergeants and burgesses whom the Saracens had dispossessed heard the word of King Guy. They set off and came to him, as did great numbers of young woman and orphans whose husbands and fathers were killed and lost in Syria. He gave rich fiefs both to the Greeks and the knights he had brought with him and to shoemakers, masons and Arabic scribes so that (may God be merciful!) they became knights and great vavasors in the island of Cyprus. He had them marry the women on their arrival as befitted their station, and he provided them out of his wealth so that those who married them would be well satisfied. He granted so much land away to those who would take it that he enfeoffed 300 knights and 200 mounted sergeants, not to mention the burgesses who lived in the cities to whom he gave substantial lands and allowances. When he had finished this distribution, he had not kept enough for himself to support 20 knights. Thus did King Guy people the island of Cyprus, and I will tell you that if the emperor Baldwin had peopled Constantinople in the same manner in which Guy had peopled the island of Cyprus he would never have lost it. For he died

1 The Conquest of Jerusalem and the Third Crusade, Sources in Translation, trans. Peter Edbury (Aldershot: Ashgate Publishing Ltd., 1996), 3-4; La continuation de Guillaume de Tyr (1184-1197), ed. Margaret Ruth Morgan (Paris: P. Geuthner, 1982), 13. 
because he wanted to retain too much of his empire in his domain, and because of this he lost it all. As the saying goes in reproof: 'Who covets all, loses all'2.

A contemporary Arabic source confirms that Guy was in friendly communication with Saladin shortly after acquiring Cyprus, thereby corroborating the assertion that Guy solicited Saladin's advice regarding his retention of Cyprus. Furthermore, by the mid-thirteenth century, when the Lyon Eracles was being written, Saladin enjoyed a high reputation in Western Europe as a man of honour. The author of this passage was possibly Ernoul, a squire of Balian of Ibelin who was a leading opponent of Guy among the nobles of the kingdom of Jerusalem. According to this hypothesis Ernoul wrote this passage in order to belittle Guy by showing that the idea to settle Cyprus originated with Saladin and that Guy had been overgenerous to people of non-noble, that is humble, social origins. If not Ernoul, the author might have been a noble cleric prejudiced against non-nobles and the base origins of the Cypriot feudatories. The assertion against Guy, however, is uncorroborated. It is also problematic inasmuch as it does not explain why at the end of the passage cited Guy is compared very favourably to the emperor Baldwin of Jerusalem, the first Latin ruler of Constantinople. What does emerge clearly from the account is that the first settlement of Cyprus following its conquest took place under Guy, the settlers had varied social, ethnic and geographical origins, although they all originated from the eastern Mediterranean basin, and that it enabled Guy and his successors to retain Cyprus ${ }^{3}$.

Another continuation of William of Tyre's Chronicle, surviving as a single manuscript in the Biblioteca Medicea-Laurenziana in Florence and known as the Florentine Eracles, has a unique text from the years 1191-1197 closely related to the abovementioned Lyon Eracles but usually more concise. The account it gives of Guy's settlement of the island of Cyprus largely replicates that of the Lyon Eracles, but it omits the section on the grant of fiefs to Greeks, Arabic scribes, shoemakers and masons. Furthermore, whereas the Lyon Eracles alludes to the burgesses being granted 'lands and allowances', the Florentine Eracles relates that they were granted 'lands and holdings.' It also states that the emperor

2 The Conquest of Jerusalem, $\$ \$ 135-136$.

3 Peter Edbury, The Kingdom of Cyprus and the Crusades 1191-1374 (Cambridge: Cambridge University Press, 1991, 1994²), 16-19, and esp. p. 17 note 19; idem, „Ernoul, Eracles and the Beginnings of Frankish Rule in Cyprus, 1191-1232", in Medieval Cyprus, A Place of Cultural Encounter, eds. Sabine Rogge, Michael Grünbart, (Münster: Waxmann Verlag GmbH, 2015), 31-37 and 43-46. 
Baldwin lost everything not on account of wishing to retain too much of his empire in his domain, but because of 'bad advice'.

The anonymous Cypriot chronicle in Italian known as 'Amadi' after its last owner, a Venetian nobleman, was probably written in the early sixteenth century but contains in Italian translation versions of earlier, and sometimes now lost, old French chronicles of the thirteenth century. For the passage relating the settlement of Cyprus after the Latin conquest the anonymous author used the so-called Colbert-Fontainebleu Continuation of the chronicle of William of Tyre, that dates to the midthirteenth century with subsequent additions ${ }^{5}$. Regarding the settlement of Cyprus, it omits all mention of Saladin, maintaining that King Guy on realising that the Templars were dissatisfied with their tenure of the island of Cyprus had discussions with them, and that they were pleased to let him have it. Then the chronicle of 'Amadi' states as follows:

He then went to Cyprus and received it from the Templars; in going, he took with him all who wished to obtain fiefs there. Once he had the land of Cyprus, he sent word to reassure the peasants and had the cities and strong points provided for. He made it known throughout the surrounding territories that all knights and turcopoles or burgesses who wanted fiefs and lands should come to him, for he would grant them to them. Whereupon people from the kingdom of Jerusalem, and from Tripoli, Antioch and Armenia came; fiefs were set at 800 bezants for a knight, 400 bezants for a turcopole with two mounts and harnesses; these were assigned in lands. He granted burgess tenures, in other words freehold properties, in the cities and so populated them ${ }^{6}$.

This account, similar to the Lyon Eracles in its description of the social antecedents and geographical origins of settlers coming to Cyprus, nevertheless contains information not found in it. It states that Guy 'sent word to reassure the peasants.' Unfortunately, it does not state what the reassurance was, but possibly the peasants were informed that they would retain their lands under conditions broadly similar to those applied during the earlier Byzantine period, the three main types of land then being imperial land, ecclesiastical land and land belonging to the Byzantine archons,

4 La continuation de Guillaume de Tyr (1184-1197), 14.

5 The Chronicle of Amadi translated from the Italian, trans. Nicholas Coureas, Peter Edbury (Nicosia: Cyprus Research Centre, 2015), \$150 and p. 487.

6 "Chronique d'Amadi”, in Chroniques d' Amadi et de Strambaldi, ed. Louis de Mas Latrie (Paris: Imprimérie Imperiale, 1891), 85; The Chronicle of Amadi, \$150. 
who following the conquest for the most part departed from Cyprus for Constantinople. In addition, this account quantifies the monetary value of the fiefs granted to knights and turcopoles, although the sums given differ from that in the Colbert-Fontainebleu Continuation, which gives these sums as 400 bezants for a knight and 300, or only 200 according to one manuscript, for a turcopole ${ }^{7}$.

It is important to note that these sums refer to white bezants. In the years 1165-1265 Latin Syria fiefs were worth at least 300 Saracen bezants and could be worth up to 1.000, with one Saracen or gold bezant being worth over three white bezants. Therefore, they were worth more than those Guy granted on Cyprus, at least if the figures given in the chronicle of 'Amadi' are accurate. Nevertheless, other accounts of the implantation of settlers on Cyprus after Guy's arrival present the value of the Cypriot fiefs more positively. One is the Chronique d'Ernoul et de Bernard le Tresorier, a narrative wholly distinct to that of Archbishop William of Tyre that begins with the establishment of the Latin states in the eastern Mediterranean following the First Crusades and concludes in 1227, or in 1231 in some manuscripts. The account of Guy's settlement of Cyprus given in Ernoul is broadly similar to that of the Lyon Eracles, but in narrating what happened after Guy's death, when his brother Aimery took possession of Cyprus, Ernoul states that Aimery realised that he had been left little land and that the fiefs Guy had given for 1.000 bezants were in fact worth double this sum. Two variant manuscripts of the Colbert-Fontainebleu Eracles Continuation of William of Tyre likewise assert that the fiefs granted on Cyprus were worth twice as much as anticipated initially, causing Aimery to summon his feudatories and require them to return some of the land given ${ }^{8}$.

The chronicle of 'Amadi' also adds the important information that Guy granted burgess tenures in the cities of Cyprus 'and so populated them'. It is possible that these cities were depopulated to some extent following the flight of the Byzantine archons and their servants and retainers from Cyprus to Constantinople after the Latin conquest, although no

7 Edbury, The Kingdom of Cyprus, 20-21, 185; Jean Richard, „Un monastère grec de Palestine et son domaine chypriote", in idem, Croisades et Etats latins d'Orient. Points de vue et Documents (London: Routledge, 1992), 70-72; The Chronicle of Amadi, 84, note 1.

8 Jonathan Riley-Smith, The Feudal Nobility of the Kingdom of Jerusalem 1174-1277 (Basingstoke: Palgrave-Macmillan, 1973, 2002²), 10; Edbury, The Kingdom of Cyprus, 17-18; The Conquest of Jerusalem, 4-5; Richard, „Un monastère grec”, 48, note 16; "Eracles': L'estoire de Eracles empereur et la conquest de la Terre d' Outremer”, in Recueil des historiens des Croisades, Historiens occidentaux, 5 vols. 1844-1895, vol. 2 (1859), VII, X, 189-190 [variant mss.]; Chronique d' Ernoul et de Bernard le Trésorier, ed. Louis de Mas Latrie (Paris: Societé de l' histoire de France, 1871), 286-288. 
source states this. But burgess tenures had long been a feature of Latin society in the kingdom of Jerusalem and the other states founded by the Crusaders in the aftermath of the First Crusade. This record of their transplantation to Cyprus from the chronicle of 'Amadi' and ultimately from the Colbert--Fontainebleu Continuation the anonymous author used for the relevant passage constitutes valuable testimony on the transplantation of burgess institutions and forms of property from Latin Syria to Cyprus at the early stages of the island's settlement. It indicates, moreover, that the grant of burgess tenures provided an incentive for peopling, or re-peopling, the island's towns. Just as the institution of fiefs was transplanted from the countryside of Latin Syria to that of Cyprus in the course of settlement, so that of burgess-tenures was transplanted from the urban environment of Latin Syria to the towns of Cyprus. Just as the rulers of the Latin kingdom of Jerusalem anxious to settle the captured cities immediately after the conquests of the First Crusade offered guarantees regarding the settlers' urban properties to encourage settlement, something similar seems to have occurred on Cyprus soon after Guy's arrival'.

The chronicle of the Cypriot Leontios Makhairas, written in Greek in the fifteenth century by someone who was ethnically Greek but whose family served the Lusignan kings of Cyprus, describes the settlement on Cyprus following the Latin conquest in terms similar to those found in the Lyon Eracles, but with important divergences. Like the Lyon Eracles, Makhairas states that Guy solicited Saladin's advice, although referring to him simply as the 'sultan' and that Saladin advised him to be generous and to give his friends and knights good fiefs, enjoining him to give generously and bring great men on his side rather than to give sparingly and lose the remainder of his realm. Makhairas adds, however, that 'the sultan' also advised him to dispatch prudent envoys, not unworthy one to his detriment, and that Guy duly sent envoys to the West, and more specifically to France, England and Catalonia, promising wealth to the rulers of those places and their sons. He then adds that numerous people from these countries came to Cyprus with their wives and children and settled there. In addition, he states that Guy gave monthly salaries to some, rents and 'assignments' by which he presumably means fiefs to others. Furthermore, he granted 'freedoms and liberties of enfranchisement', by which manumission from the status of serfdom is possibly meant. Syrian settlers were granted the privilege of paying one half of

9 „Chronique d'Amadi”, The Chronicle of Amadi, \$150; Joshua Prawer, „Burgage-tenure” in idem, Crusader Institutions (Oxford: Oxford University Press, 1980, 19982), 255-258. 
the standard tolls when buying and selling goods, as well as exemption from paying the dues paid by the indigenous inhabitants ${ }^{10}$. It is hard to ascertain whence Makhairas's account originates with regard to these divergences, especially the section concerning the arrival of settlers from Western Europe, not simply the eastern Mediterranean basin. Perhaps he was using a lost version of the various Continuations of William of Tyre. Alternately, he was simply referring to the arrival of merchants from Provence and Catalonia taking place from the thirteenth century onwards, and that of mercenaries from France and England occurring in the fourteenth century ${ }^{11}$.

Makhairas goes on to affirm that 'many Syrians and many Latins came and settled in Cyprus', thereby acknowledging the overall success of Guy's policies. According to Makhairas, however, the settlers themselves invoked the rebellion of the Greeks of Cyprus against the Templars that took place in 1192 to insist on preferential treatment in the dispensation of justice. Specifically, they demanded that their word should prevail over that of the natives in disputes with them, and that natives' testimony should not be valid against that of vassals and fiefholders, even if corroborated by royal testimony, unless the vassal in question freely acknowledged it to be true. This passage is clearly a reflection of the feudal law prevailing on Cyprus, which debarred Greeks from becoming vassals or from witnessing royal charters. In many instances Greeks and other non-Latins could not testify against a Latin in the High Court, while even in instances where they could the Latins' testimony was preferable. Makhairas provides a reason for this legal discrimination; it was implemented 'to eliminate the arrogance of the Greeks so that they would not rebel as they had done against the Templars'. As someone who was ethnically Greek, this discrimination clearly rankled with Leontios Makhairas, despite the fact that he had his family served the royal court of the Lusignan kings. He makes it clear, moreover, that the Syrians as well as the Latins were privileged in relation to the Greeks. Indeed, they were privileged in the legal as well as the commercial spheres, for the

10 Leontios Makhairas, Recital concerning the Sweet Land of Cyprus entitled 'Chronicle', 2 vols., ed. and trans. Richard M. Dawkins (Oxford: Clarendon Press, 1932), I, \$\$ 25-26.

11 Nicholas Coureas, „Provencal Trade with Cyprus in the Thirteenth and Fourteenth Centuries”, Epeterida Kentrou Epistemonikon Ereunon XXII (1996): 69-92; idem, „Profits and Piracy: Commerce between Cyprus and Catalonia from 1291 to 1420”, Epeterida Kentrou Epistemonikon Ereunon XXIII (1997): 27-55; idem, „The Perception and Evaluation of Foreign Soldiers in the Wars of King Peter I of Cyprus: The Evidence of the Cypriot Chronicles and its Shortcomings", The Medieval Chronicle 11 (2017): $108-126$. 
testimony of Syrians in boundary disputes was considered preferable to those of Greeks according to Philip of Novara's treatise on the procedures and law of the High Court of Cyprus ${ }^{12}$.

Florio Bustron, a chronicler of Syrian origin who wrote his history in the second half of the sixteenth century, gives an account of the settlement of Cyprus following the Latin conquest resembling that of the Lyon-Eracles in its general outlines. He states that Guy brought many French nobles to Cyprus with him on receiving it from the Templars, as well as others wishing to have a salary, perhaps a reference to salaried knights. He made it known to noble knights, turcopoles and burgesses in the lands around Cyprus desiring fiefs, incomes from lands, estates or casalia that they should come thither, for he would grant them fine residences and good lands. Numerous people arriving from Jerusalem, Tripoli, Antioch and Armenia obtained fiefs, but the monetary values given for these fiefs differ somewhat from those given in the chronicle of 'Amadi' and are given in ducats, the standard Venetian currency. Those for knights were worth 80 ducats, those for squires 60 ducats, those for men-at-arms and turcopoles with two horses 40 ducats and those for turcopoles with one horse 20 ducats. He also granted them horses and weaponry, and assigned lands to them, while granting burgess tenures, that is fixed properties, in the towns, which were thus populated very well. Florio Bustron's mention of the grant of burgess tenures, not found in the Lyon Eracles, is clearly taken either from the chronicle of 'Amadi' or from a source used by both chronicles. Leontios Makhairas states that in 1306 the Venetian ducat was worth ten white bezants, but he is probably giving the value it had during his time, the first half of the fifteenth century. Nevertheless, if one accepts this value, then the values of the fiefs stated in the chronicle of Florio Bustron correspond roughly to those given in 'Amadi' although Florio Bustron has four gradations as opposed to the two given in 'Amadi'13.

Stephen of Lusignan, a Dominican friar descended from the Lusignan royal house, wrote both of his chronicles, the Chorograffia of 1573 and

12 Leontios Makhairas, Recital concerning, I, \$27; Peter Edbury, „The Lusignan Regime in Cyprus and the Indigenous Population", in Kingdoms of the Crusaders from Jerusalem to Cyprus, XX, ed. Peter Edbury (Farnham: Ashgate Publishing Ltd., 1999), 5; Philip of Novara, Le Livre de Forme du Plait, ed. and trans. Peter Edbury (Nicosia: Cyprus Research Centre, 2009), 80-82 [text] and 236-238 [translation], also 131-135 [text] and 265-268 [translation]).

13 Florio Bustron, „Chronique de l' île de Chypre”, ed. Louis de Mas Latrie, Collections des documents inédits sur l' histoire de France: mélanges historiques V (1886), 52; Leontios Makhairas, Recital concerning, II, 47; „Chronique d'Amadi”, 85; The Chronicle of Amadi, $\$ 150$. 
the Description of 1580, after the conquest of Cyprus by the Ottoman Turks, these works being published in Bologna and Paris respectively. Both works allude to the settlement that took place in Cyprus under King Guy. Passages in both the Chorograffia and the Description allude to King Guy went to Cyprus, going there with his court and many nobles, while the Description adds in the relevant passage that he provided at least 300 knights 'of the golden spurs' with estates, giving more or fewer villages to each one, without quantifying the value of the estates given. In both passages mentioned above the year of King Guy's arrival is given mistakenly as 1193. In another passage the Chorograffia states that Saladin on taking Jerusalem did not expel the various nations from the Holy Sepulchre except for the Latins, Greeks, Armenians, Copts and Maronites. The others, namely the Indians, Nestorians, Georgians and Jacobites remained there as previously. When King Guy, however, went to Cyprus, some people from each nation accompanied him there, with the king granting them places in the city of Nicosia for building their churches and houses. The Description also contains a second passage on the settlement of Cyprus, in which it is stated that on becoming lord of Cyprus Guy brought over many people, noble and otherwise, from Jerusalem, Tripoli, the principality of Antioch and the kingdom of Lesser Armenia to Cyprus. He granted them offices, dignities, privileges, lordships and villages, appointing 300 knights 'of the golden spurs' and 200 squires as members of the nobility. This second passage, especially the figures of 300 knights and 200 squires, is clearly a summary of the Lyon Eracles passage on settlement in Cyprus after the Latin conquest. As in the Chorograffia, however, the date of Guy's arrival in Cyprus is given wrongly as $1193^{14}$.

\section{Documentary Sources on the first Latin Settlers in Cyprus and other Mediterranean Lands}

Having examined the accounts of the chroniclers, one turns to the other sources of evidence regarding settlement on Cyprus in the years following the Latin conquest of 1191 . The few extant charters from this period provide lists of witnesses and so constitute a valuable non-narrative source ${ }^{15}$. It is noteworthy that they largely confirm the chronicle

14 Stephen de Lusignan, Chorograffia et breve historia dell' isola de Cipro principiando al tempo di Noé per il fino al 1572 (Bologna: per Alessandro Benaccio, 1573), fols. 34r and 49v; idem, Description de toute l' isle de Chypre (Paris: chez Guillaume Chaudiere, 1580 ), fols. $67 \mathrm{v}$ and $77 \mathrm{r}$.

Edbury, The Kingdom of Cyprus, 18, note 23. 
accounts as regards immigration to Cyprus from Latin Syria, although some of the settlers, as appears from their surnames, ultimately originated from France. One of the charters, a donation by Guy de Lusignan, king of Jerusalem and lord of Cyprus, of the annual incomes of the market taxes of Nicosia, amounting to 200 white bezants, to the Cistercian abbey of Jubin in Syria on 18 August 1194, was witnessed by Aimery the constable, Humphrey of Toron, the marshal Hugh Martin, Aimery of Rivet, Renier of Jubail, Walter le Bel and Eudes de Mayre. These were Guy de Lusignan's most prominent followers when he took possession of Cyprus in 1192. Aimery the constable was his brother and successor, to be crowned king of Cyprus in 1197. Humphrey of Toron was the husband of Isabella, a half-sister of Sibylla the queen of Jerusalem, while Hugh Martin had been the marshal of Jerusalem in 1191. Aimery of Rivet became the seneschal of Cyprus in 1197. Before April or May 1196 Guy's successor Aimery sent Renier of Jubail, descended from or identical to a namesake recorded in 1160-1161 as a vassal $f$ the lord of Caesarea, as his ambassador to the German emperor Henry VI so as to request a crown for him, which was duly granted. In 1197 Aimery was formally crowned as king of Cyprus. Walter le Bel had been formerly viscount at Acre and had a fief there or nearby, while Eudes de Mayre seems to have originated from Antioch, although nothing else in known about him ${ }^{16}$.

Hugh Martin, Aimery of Rivet, Renier of Jubail and Walter le Bel appear as witnesses in another charter of Aimery de Lusignan dated 29 September 1195. It records his donation of some lands and a chapel located in Nicosia to the abbot and canons of the Holy Sepulchre, who had moved to Acre following the loss of Jerusalem in 1187. Aimery received a ruby that weighed 2.5 bezants in return for this grant. Other recorded witnesses were the constable Baldwin of Bethsan, one of the sons of Gramont, lord of Bethsan in Latin Syria, Raynald Betlay, a name not encountered elsewhere but probably denoting someone from Latin Syria and Alan le Bel, perhaps a brother of Walter le Bel. The witnesses Baldwin of Hostiarius and Baldwin of Neuville were possibly related to others with the same surnames, resident in the Latin kingdom of Jerusalem in the twelfth century. Masters Peter Vulasco and Master Bernard are of unknown origin but the latter is described as a doctor, an early

16 Jean Richard, „L' abbaye cistercienne de Jubin et la prieuré Saint-Blaise de Nicosie”, in idem, Orient et Occident au Moyen Age: Contacts et relations (XXe-XVe s.) (London: Variorum Reprints, 1976), 69-70 and note 27; Edbury, The Kingdom of Cyprus, 19, $25,31$. 
example of the emigration of doctors to recently conquered Cyprus ${ }^{17}$. A third charter dated May 1196 records how 'Guy' de Lusignan, clearly a scribal error for his brother Aimery, Guy having died at the end of 1194, as king of Cyprus granted in honour of the German emperor Henry VI and at the request of the archbishop of Trani in Italy, who had brought Aimery his royal sceptre, the right to trade freely in Cyprus without paying customs duties. The witnesses included Aimery of Rivet, Philip the brother of Baldwin of Bethsan, Walter le Bel and his brother 'Ailelmus', probably a scribal error for 'Guillelmus', namely William, Renier of Jubail, whose first name was misspelt as 'Raymericus', and Adam of Antioch. The others were Raynald of Barlais, whose family was related to the Berlay lords of Montreuil Bellay on the boundary dividing Poitou from Anjou in France. The final witness, Simon of Paphos, is of unknown origins and perhaps held a fief in Paphos ${ }^{18}$.

A fourth charter dated 22 November 1197 recording the grant of the casale of Livadi in Cyprus by King Aimery to Archbishop Joscius of Tyre was witnessed by the above mentioned Aimery of Rivet, Renier of Jubail, Adam of Antioch, Simon of Paphos and Baldwin of Hostiarius. The other witnesses were Reynald of Soissons, who held a fief at Nablus in Palestine, and the brothers William and Roland of la Baume who were perhaps descended from Raymond of la Baume, a knight from Tripoli in Latin Syria. The witness Helias de 'Robore' must refer to Helies dou Rouvre, a vassal of the lord of Tiberias in Palestine who possessed the casale of Avlona in Cyprus and whose daughter Isabel married Lawrence of Morphou, whose family had arrived in Cyprus with Guy de Lusignan ${ }^{19}$. Finally, a charter dated March 1201 in which King Aimery the Latin patriarch of Jerusalem and his cathedral chapter the casale of Pendaschinos on Cyprus and its dependencies with the exception of the fountain of St George and ten carrucates of land, already granted to the Teutonic Order, was witnessed by the aforementioned Aimery of Rivet, Renier of Jubail, Reynald of Soissons, Reynald and William of la Baume, Simon of Paphos, Baldwin Hostiarius and Rustanus Aymar. The last witness,

17 The Cartulary of the Cathedral of the Holy Wisdom of Nicosia, eds. Nicholas Coureas, Christopher Schabel (Nicosia: Cyprus Research Centre, 1997), 141-142, no. 45; Edbury, The Kingdom of Cyprus, 19.

18 Louis de Mas Latrie, Histoire de l'île de Chypre sous le règne des princes de la maison de Lusignan, vol. 2 (Paris: Imprimerie Impériale, 1852-1861), 30; Edbury, The Kingdom of Cyprus, 18, note 25, 18-19 and 31.

19 The Cartulary of the Cathedral, 142-143, no. 46; Edbury, The Kingdom of Cyprus, 19; Marie-Adélaïde Nielen, Lignages d'Outremer, introduction, notes et edition critique, Documents relatifs à l'histoire des croisades, XVIII (Paris: L'Académie des Inscriptions et Belles Lettres, 2003), 125-126, 193. 
not mentioned in the earlier charters discussed above, is otherwise unknown ${ }^{20}$. Overall, the documents examined above indicate a relatively small group of noble families from Latin Syria accompanying Guy de Lusignan to Cyprus and serving him and his brother, the future King Aimery of Cyprus.

The Cypriot and other chronicles form the main source for Latin settlement on the island after 1191, and the few documents dating from the first decade after the Latin conquest broadly confirm the picture provided by the chronicles. Whether chronicles are the main source for Latin settlement elsewhere in the Eastern Mediterranean should now be examined for purposes of comparison, and in order to place the picture emerging from Cyprus within a wider context. As with Cyprus, the information on early settlers in the Latin kingdom of Jerusalem and in the other states founded by Latins in Syria after the First Crusade of 1099 is largely though not wholly derived from contemporary chronicle accounts, notably those of Albert of Aachen, Fulcher of Chartres and the Armenian Chronicle of Matthew of Edessa, as well as the Chronicle of William of Tyre, written in the last quarter of the twelfth century. Fulcher of Chartes observed that many of those participating in the capture of Jerusalem were allowed to keep whatever they had seized, so that numerous poor persons suddenly acquired wealth. Albert of Aachen records that Godfrey of Bouillon, elected king of Jerusalem in 1099, kept a select group of men around him who had decided to remain in the Holy Land. The chronicler styles them the domus Gotefrid $i^{21}$. In this respect Godfrey resembles Guy de Lusignan, who brought a tight-knit group of men from Latin Syria over to Cyprus to serve him when he acquired the island in 1192.

Alfred of Aachen also records that Godfrey issues a decree stating that every year a written record should be compiled of those who had remained for one year and one day in their tenures, a measure promulgated in order to prevent persons who had departed from the Holy Land from returning and claiming property after a year had passed. William of Tyre, moreover, records that after Godfrey's death in July 1100 his successor Baldwin of Boulogne assembled all holders of fiefs so that they would account for their holding and swear fealty to him, whereupon he returned to each of them the fiefs they possessed. Albert of Aachen and Fulcher of Chartes describe Baldwin's journey from Edessa to Jerusalem

20 Le cartulaire du chapitre du Saint-Sépulchre de Jérusalem, in Documents relatifs à l'histoire des croisades, ed. Geneviève Bresc-Bautier (Paris: L'Académie des Inscriptions et Belles-Lettres, 1984), 331-332, no. 174.

21 Malcolm Barber, The Crusader States (Yale: Yale University Press, 2012), 17, 53. 
via Antioch, and the Armenian chronicler Matthew of Edessa described how Baldwin subjected the population of Edessa to harrowing extortions in order to finance his expedition to Jerusalem, for he set out with a force of nearly 200 knights and 700 infantry men ${ }^{22}$. Not all the information on the early settlement in the kingdom of Jerusalem derives from chronicle accounts, however. The freemen originating from Western Europe who populated the twenty-one casalia in the kingdom of Jerusalem granted by Godfrey of Bouillon to the canons of the Holy Sepulchre in the region north of Jerusalem, after being elected king, are known from the record of this grant preserved in the cartulary of the chapter of the Holy Sepulchre, the greater part of which was compiled in around $1165^{23}$.

The republic of Venice acquired Crete in 1211 after the Fourth Crusade of 1204, just twenty years after the conquest of Cyprus in 1191 by King Richard I of England. The sources recording the settlement of Venetians on Crete, however, are documentary as opposed to narrative. The charter known as the Concessio insulae Cretensis drawn up by the Venetian government in 1211 recorded the first settlement of Crete by a group consisting mostly of Venetian subjects. According to its terms, Crete was divided in six districts in imitation of the six neighbourhoods of the city of Venice. These districts, the sestieri, were subdivided into thirty-three and one third units of land called cavallerie or milicie, with the former being given exclusively to Venetians and the latter mainly to nonVenetians, probably mercenaries originating from Northern Italy. A later document of 1222 records more cavallerie being established around the city of Rethymnon in north-west Crete, an indication of the Venetian republic's concern to strengthen its hold on the island by encouraging settlement. The source material recording early settlement on Crete by Venetians and other Italians, however, is exclusively documentary, with no narrative accounts to supplement such evidence ${ }^{24}$.

As regards Rhodes, an Aegean island that the Roman Catholic military order of St John, also known as the Hospitallers, conquered in 1309 from Byzantium, the evidence for Latin settlement following the conquest is wholly documentary. The relevant documentation derives mainly from texts copied into the partes cismarinae sections of the four earliest surviving Hospitaller registers covering the years 1347-1348, 1351-1352, 1358-1359 and 1365-66. These are supplemented by a parchment of 1338 ,

22 Ibidem, 54, 62.

23 Ibidem, 17.

24 Sally McKee, Uncommon Dominion: Venetian Crete and the Myth of Ethnic Purity (Philadelphia: University of Pennsylvania Press, 2000), 32-37. 
a text of 1339 and two parchments of 1347 and 1364, all published by Anthony Luttrell. This documentary evidence records the grant of casalia on Rhodes to Hospitaller knights who paid rents for them in return, the grant of lands to Latins who did not belong to the Hospitaller Order from 1313 onwards, the lands being held in return for military service, sometimes commuted to a money payment or even for the service of armed galleys. By 1335 feudal tenures, that had not attracted numerous settlers, were being replaced by leases. Latin settlers acquired major and minor grants of land and Greeks were also granted lands to be held in leasehold. The tenure in such cases could be for a prescribed number of years, for life or in perpetuity with the right to bequeath the land. Besides Latins and Greeks, Cypriots and Syrians also settled on Hospitaller Rhodes, during the fourteenth and fifteenth centuries, a settlement recorded through the documentation of the Order itself, not through narrative accounts ${ }^{25}$.

To conclude, one can state that the various accounts of settlement on Cyprus following its cession to King Guy of Jerusalem in 1192 show variations as regards the value of the fiefs, the geographical areas from which the settlers originated and the types of properties granted to the incoming settlers. The chronicle of 'Amadi' in referring to the early introduction of burgess tenure to Cyprus and its towns provides information not found in the Lyon-Eracles and its derivatives. The chronicle of Leontios Makhairas likewise adds significant information absent from the Lyon-Eracles, stating that settlers arrived from Western Europe as well as from the eastern Mediterranean lands adjacent to Cyprus, and that both Syrians and Latins were granted legal and financial privileges not enjoyed by the island's indigenous Greek population, an assertion corroborated by legal texts. Overall, however, the information found in the detailed account of the settlement of Cyprus under King Guy given in the Lyon-Eracles is repeated, although usually only in part or in summary fashion, in later chronicles alluding to the settlement. The Latin kingdom of Jerusalem resembles Cyprus in that the source material for early Latin settlement is narrative, not documentary. But this is not the case for Venetian Crete and Hospitaller Rhodes, where the source materials recording the arrival of the first Latin settlers are wholly documentary.

25 Anthony Luttrell, „Settlement on Rhodes, 1306-1366”, in idem, The Hospitallers of Rhodes and their Mediterranean World (Aldershot: Ashgate Publishing Ltd., 1992), 273281; Coureas Nicholas, „The Migration of Syrians and Cypriots to Hospitaller Rhodes in the Fourteenth and Fifteenth Centuries", in The Hospitallers, the Mediterranean and Europe: Festschrift for Anthony Luttrell, eds. Karl Borchardt, Nikolas Jaspert, Helen J. Nicholson (Aldershot: Ashgate Publishing Ltd., 2007), 101-107. 


\section{Bibliography}

\section{Primary Sources}

Bustron Florio, „Chronique de l' île de Chypre”, ed. Louis de Mas Latrie, Collections des documents inédits sur l' histoire de France: mélanges historiques $\mathrm{V}(1886)$.

"Chronique d'Amadi", in Chroniques d' Amadi et de Strambaldi, ed. Louis de Mas Latrie (Paris: Imprimérie Imperiale, 1891).

Chronique d' Ernoul et de Bernard le Trésorier, ed. Louis de Mas Latrie (Paris: Societé de l' histoire de France, 1871), 157.

„Eracles: L' estoire de Eracles empereur et la conquest de la Terre d' Outremer", in Recueil des historiens des Croisades, Historiens occidentaux, 5 vols. 1844-1895, vol. 2 (1859).

Le cartulaire du chapitre du Saint-Sépulchre de Jérusalem, In Documents relatifs à l'histoire des croisades, ed. Geneviève Bresc-Bautier (Paris: L'Académie des Inscriptions et Belles-Lettres, 1984).

Lusignan Stephen de, Chorograffia et breve historia dell' isola de Cipro principiando al tempo di Noé per il fino al 1572 (Bologna: per Alessandro Benaccio, 1573).

Lusignan Stephen de, Description de toute l' isle de Chypre (Paris: Chez Guillaume Chaudiere, 1580).

Makhairas Leontios, Recital concerning the Sweet Land of Cyprus entitled 'Chronicle', 2 vols., ed. and trans. Richard M. Dawkins (Oxford: Clarendon Press, 1932).

Nielen Marie-Adélaïde, Lignages d'Outremer, introduction, notes et edition critique, Documents relatifs à l'histoire des croisades, XVIII (Paris: L'Académie des Inscriptions et Belles Lettres, 2003).

Philip of Novara, Le Livre de Forme du Plait, ed. and trans. Peter Edbury (Nicosia: Cyprus Research Centre, 2009).

The Cartulary of the Cathedral of the Holy Wisdom of Nicosia, eds. Nicholas Coureas, Christopher Schabel (Nicosia: Cyprus Research Centre, 1997).

The Chronicle of Amadi translated from the Italian, trans. Nicholas Coureas, Peter Edbury (Nicosia: Cyprus Research Centre, 2015).

The Conquest of Jerusalem and the Third Crusade, Sources in Translation, trans. Peter Edbury (Aldershot: Ashgate Publishing Ltd., 1996).

\section{Secondary Literature}

Barber Malcolm, The Crusader States (Yale: Yale University Press, 2012).

Coureas Nicholas, „Provencal Trade with Cyprus in the Thirteenth and Fourteenth Centuries", Epeterida Kentrou Epistemonikon Ereunon XXII (1996): 69-92.

Coureas Nicholas, „Profits and Piracy: Commerce between Cyprus and Catalonia from 1291 to 1420", Epeterida Kentrou Epistemonikon Ereunon XXIII (1997): 27-55. 
Coureas Nicholas, „The Migration of Syrians and Cypriots to Hospitaller Rhodes in the Fourteenth and Fifteenth Centuries", in The Hospitallers, the Mediterranean and Europe: Festschrift for Anthony Luttrell, eds. Karl Borchardt, Nikolas Jaspert, Helen J. Nicholson (Aldershot: Ashgate Publishing Ltd., 2007), 101-107.

Coureas Nicholas, „The Perception and Evaluation of Foreign Soldiers in the Wars of King Peter I of Cyprus: The Evidence of the Cypriot Chronicles and its Shortcomings", The Medieval Chronicle 11 (2017): 108-126.

Edbury Peter, The Kingdom of Cyprus and the Crusades 1191-1374 (Cambridge: Cambridge University Press, 1991, 1994²).

Edbury Peter, „The Lusignan Regime in Cyprus and the Indigenous Population”, in Kingdoms of the Crusaders from Jerusalem to Cyprus, XX, ed. Peter Edbury (Farnham: Ashgate Publishing Ltd., 1999), 1-9.

Edbury Peter, „Ernoul, Eracles and the beginnings of Frankish Rule in Cyprus, 1191-1232", in Medieval Cyprus, A Place of Cultural Encounter, eds. Sabine Rogge, Michael Grünbart (Münster: Waxmann Verlag GmbH, 2015), 29-51.

La continuation de Guillaume de Tyr (1184-1197), ed. Margaret Ruth Morgan (Paris: P. Geuthner, 1982).

Luttrell Anthony, „Settlement on Rhodes, 1306-1366”, in idem, The Hospitallers of Rhodes and their Mediterranean World (Aldershot: Ashgate Publishing Ltd., 1992), 273-281.

Mas Latrie Louis de, Histoire de l'île de Chypre sous le règne des princes de la maison de Lusignan, vol. 2 (Paris: Imprimerie Impériale, 1852-1861).

McKee Sally, Uncommon Dominion: Venetian Crete and the Myth of Ethnic Purity (Philadelphia: University of Pennsylvania Press, 2000).

Prawer Joshua, „Burgage-tenure” in idem, Crusader Institutions (Oxford: Oxford University Press, 1980, 1998²), 250-262.

Richard Jean, „L' abbaye cistercienne de Jubin et la prieuré Saint-Blaise de Nicosie", in idem, Orient et Occident au Moyen Age: Contacts et relations (XXe-XVe s.) (London: Variorum Reprints, 1976), 63-74.

Richard Jean, „Lordonnance de décembre 1296 sur le prix du pain à Chypre”, in idem, Orient et Occident au Moyen Age: Contacts et Relations (XIIe-XVe s.) (London: Variorum Reprints, 1976, 19974), 45-51.

Richard Jean, „Un monastère grec de Palestine et son domaine chypriote”, in idem, Croisades et Etats latins d'Orient. Points de vue et Documents (London: Routledge, 1992), 61-75).

Riley-Smith Jonathan, The Feudal Nobility of the Kingdom of Jerusalem 1174-1277 (Basingstoke: Palgrave-Macmillan, 1973, 2002²). 